\title{
BEANNACHT (BLESSING)
}

\author{
Linda Buckley
}

What can I add to the beautiful tributes already written? Just one thought prevails - what if nobody else understands or believes in me as much as Bob did? With his steady wisdom and advice, Bob's was a guiding voice through those tentative early years of being a composer. He was fiercely loyal and I am so blessed to have had such a wonderful friend in him for the past ten years, hanging out and endlessly chatting in Dublin, London, Amsterdam, Belgium.

We first met at a concert in Dublin, and soon afterwards he interviewed me for the Contemporary Music Centre in Ireland. This later led to an article on my work for the Journal of Music. When he sent me a first draft, based on conversations and from his own listening, I was quite taken aback; what he had written was astoundingly insightful - it not only showed a deep understanding of my musical thinking, but of me as a person, the essence of all I do:

Buckley engages with an area of experience that new music is generally shy of, which, simplified and reduced to a single word, I'd call ecstasy. Not the drug-induced euphoria of dance music, but exultant, heightened states of being that are the product of an excitable sensibility, of an emotional response to the world that sees the bright places of life as clearly as the dark. A line from the text she set to music in $Q$ (by the 13th-century Persian poet Jalal ad-Din Muhammad, known as Rumi) reads: 'Become the sky./ Take an axe to the prison wall./ Escape./ Walk out like someone suddenly born into colour.'(Bob Gilmore, Journal of Music, 2008).

I worked on a number of new pieces with Bob, Elisabeth and Alfrun for Trio Scordatura - each felt like a discovery, an adventure, from whiskey bars of Amsterdam to driving through fields in the Belgian countryside. It is no coincidence that the Dublin new music scene is in such a healthy and active state: Bob's close relationship with various composers and musicians there, over the past ten years in particular, helped to spawn the burgeoning sense of a DIY aesthetic, that we should just get on with putting on concerts, writing music, gaining in confidence. He believed in this scene, and his support and encouragement has seen wonderful new projects thrive there, such as the Ergodos collective, spanning an ensemble, record label and production company, as well as a host of young composers who have felt inspired to take part in this new and exciting world, fired up by a tangible sense of something in the air, an atmosphere of change.

So many close friendships grew out of this. His witty and warm presence at concerts was always special, and his absence is particularly felt. He will of course be remembered for his many achievements in musical writing and performance, but it is his warmth and friendship that remain, as such treasured memories.

One piece we worked on together was called Beannacht, meaning 'blessing' in Gaelic. It was based on a poem by the late Irish writer and philosopher John O'Donohue that was originally intended as a blessing or comfort for those who may be grieving the loss of a 
loved one. I immediately remembered the words as I heard the sad news that day, on the second day of this new year:

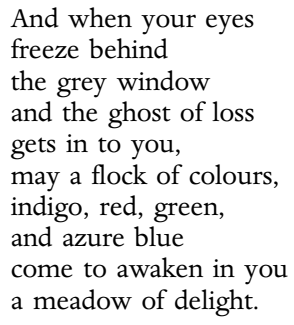

Our last correspondence was at the end of September, when Bob wrote to me to say that he had just listened to a new piece of mine for choir and orchestra, and how proud he was of me. He gave a detailed account of the music, showing his keen ear in full flow. His last words to me were 'Keep the music coming!' which was pure Bob, utterly selfless and giving. I am so glad that I then thanked him for being a dear friend and supporter over the years. I never heard from him again. It is with such strange sadness that I realise I won't see another mail in my inbox full of fun and exclamation marks, inviting me to embark on yet another great microtonal adventure with him and with Trio Scordatura.

The ways in which he has impacted on my life are immeasurable, going beyond composing through to his approach to teaching which has inspired my own teaching philosophy, now all about human connection and inspiring passion for the music that we love. I can already see that his legacy is far-reaching - I know that I will keep his spirit close to my heart, his words of encouragement echoing through the coming years. 